\title{
CHANGES IN THE MORPHOLOGY AND ULTRASTRUCTURE OF THE DUFOUR'S GLAND DURING THE LIFE CYCLE OF THE BUMBLE BEE QUEEN, BOMBUS TERRESTRIS L. (HYMENOPTERA: BOMBINI)
}

by

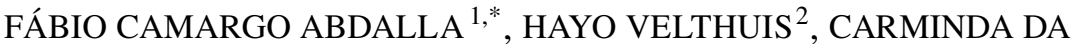 CRUZ-LANDIM $^{1}$ and MARIE JOSÉ DUCHATEAU ${ }^{2}$}

\section{$\left({ }^{1}\right.$ Departamento de Biologia, Instituto de Biociências de Rio Claro, UNESP, Caixa} Postal 199, 13506-900 Rio Claro, SP, Brazil; ${ }^{2}$ Vergelijkende Fysiologie, Projectgroep Ethologie \& Socio-Oecologie, Universiteit Utrecht, P.O. Box 80086, 3508 TB Utrecht, The Netherlands)

\begin{abstract}
The Dufour's gland is found closely associated with the sting apparatus of all female hymenopterans, playing multiple roles among bees. In some species of Bombus the gland may be involved in production of nestmate recognition pheromones, but in B. terrestris its function is not certain yet. The morphology of the Dufour's gland of B. terrestris queens and the ultrastructural features of its cells were studied in different ages and behavioural stages using routine transmission electron microscopy. Measurements of the length and the diameter of the gland in the same conditions were also made. The Dufour's gland of the queen increases significantly in size (both in length and in diameter) with age and reproductive activity. The ultrastructural features of the gland show electrondense material that comes from the haemolymph. This material is also present in the intercellular spaces, and is conducted to the subcuticular space, to be released directly into the glandular lumen. Hence at least part of the secretion is probably taken up directly from the haemolymph. The ultrastructural features indicate a more active phase of the gland corresponding to the period of egg-laying of the queen, and a decrease in activity when the queen is in hibernation as well as after the competition point. In conclusion, the gland is probably involved in reproduction, more specifically, in the marking of eggs.
\end{abstract}

KEY WORDS: Dufour's gland, bumble bee, queen, Hymenoptera, morphology, ultrastructure.

\section{INTRODUCTION}

Exocrine glands play a fundamental role in social hymenopterans, producing a plethora of pheromones that are involved in most social interactions. The Dufour's gland (DUfOUR, 1841), one of two exocrine glands

*Corresponding author; E-mail: fabdalla@ rc.unesp.br 
associated with the sting apparatus, is found in all female hymenopteran s (BORDAS, 1894; LELLO, 1968), located ventrally to the venom gland and opening, in bees, into the dorsal vaginal wall (BILLEN, 1987).

In solitary bees the Dufour's gland has many functions, including the production of a hydrophobic material used as nest cell lining (CANE, 1981; KRONEnbERG \& HefETZ, 1984), pheromones for sex (SMITH et $a l ., 1985)$ or nestmate attraction (HEFETZ, 1990), nest entrance marking (SHIMRON et al., 1985), trail pheromones (VINSON et al., 1978) and also as larval food (NORDEN et al., 1980).

The role of the Dufour's gland in social bees is not certain yet. Queens of Apis and Bombus have a larger Dufour's gland than workers (CRUZLANDIM, 1967) and, in Apis, the gland produces wax-like esters that are not found in the secretions of workers, except of egg-laying workers (KATZAV-GOZANSKY et al., 1997). Because of the localization of its opening, its size, and its caste-specific pheromones in honey bees, it has been suggested that the gland may play a role in reproduction, producing egg-marking pheromones which may be involved in the marking of the queen eggs to prevent them from being devoured by inspecting workers (RATNIEKS, 1993, 1995; KATZAV-GOZANSKY et al., 1997).

Although much progress has been made in the elucidation of the chemical composition of its secretion and its function, the morphology and the ultrastructure of the Dufour's gland, including its changes during the life of bees or during the colony cycle, as well as the differences between the castes of social bees, are largely unknown. The purpose of this study, therefore, was to describe the principal morphological and ultrastructural features of the Dufour's gland of the Bombus terrestris queen at different ages and behavioral stages in an attempt to elucidate the possible function of this gland.

\section{MATERIAL AND METHODS}

Measurements of the length and the diameter of the gland were made in Bombus terrestris L. queens. This concerned: newly emerged queens (NE), 6-day old qeens that were ready to mate (6D), queens at the end of hibernation $(\mathrm{EH})$, queens producing the first brood of the colony (1B), and queens from colonies after the competition point (ACP), with egg-laying workers (DUCHATEAU \& VELTHUIS, 1988).

The queens were collected from colonies maintained at the Department of Comparative Physiology (Utrecht University, The Netherlands) and dissected directly in fixative solution. The glands were measured with an ocular micrometer adapted to a microscope. Variance analysis (Scheffé 
F-test) with a 5\% level of significance was used to verify differences among the queen groups.

Some glands of each group were fixed with Karnovski fixative (2\% glutaraldehyde and $4 \%$ paraformaldehyde in $0.2 \mathrm{M}$ phosphate buffer at $\mathrm{pH}$ 7.3) for transmission electron microscopy (TEM), washed twice in $0.2 \mathrm{M}$ phosphate buffer, post-fixed in $1 \%$ osmium tetroxide in the same buffer, stained with $2 \%$ uranyl acetate in $10 \%$ alcohol, and dehydrated in a series of increasing concentrations of acetone, embedded in Epon resin, following usual procedures. Thin sections were cut with a diamond knife, contrasted with lead citrate, and examined in an electron microscope.

\section{RESULTS}

\section{General morphology and ultrastructu re}

The length of the Dufour's gland varies among the queens. In NE, 6D, and $\mathrm{EH}$ queens, the length is statistically equal, while $1 \mathrm{~B}$ and $\mathrm{ACP}$ queens have significantly longer glands. The diameter demonstrated a great variability among the queen groups. Like the length of the gland, the diameter increases with increasing age and reproductive activity of the queen (Table 1).

The glandular monolayered epithelium presents columnar cells lined on the luminal surface by a non differentiated cuticle. The cytoplasm of the cells has numerous polymorphic mitochondria that are randomly distributed in cells of young queens, but in older ones they can aggregate apically or basally, following the plasmic membrane invaginations often present in these cells. Smooth endoplasmic reticulum (SER), polyribosomes and some Golgi complexes as well as some secretion granules or vesicles were also observed (Fig. 1).

The intercellular space is very sinuous and, when opened, is often penetrated by the basal lamina and filled with electron dense material (Figs 3B, C). Very specialised structures are formed by invaginations of the basal and the lateral plasmic membrane into the cell, producing looplike infoldings, often with just a single mitochondrion inside (Fig. 3C).

\section{Ultrastructural distinction between the developmental phases of the queen}

The cytoplasm of the secretory cells of NE queens contains abundant polyribosomes and mitochondria, but few other organelles, inclusions and vesicles. Some cytoplasmic structures presenting a double membrane with a ground matrix containing electron-dense granules inside were observed. 


\section{TABLE 1}

The length and diameter of Dufour's glands of Bombus terrestris queens and variance analyses between the groups.

\begin{tabular}{|c|c|c|c|c|c|c|c|}
\hline \multirow[t]{2}{*}{ Qeens } & \multirow[t]{2}{*}{$\mathrm{N}+$} & \multicolumn{3}{|c|}{ Length $^{*}$} & \multicolumn{3}{|c|}{ Diameter $^{*}$} \\
\hline & & Mean & F-Test ${ }^{* * *}$ & $\mathrm{SD}^{* *}$ & Mean & F-Test & $\mathrm{SD}^{* *}$ \\
\hline Newly Emerged & 10 & 6.45 & A & 1.10 & 0.50 & A & 0.10 \\
\hline 6-Day-Old & 10 & 6.60 & A & 0.80 & 0.80 & B & 0.10 \\
\hline End of Hibernation & 12 & 6.00 & A & 1.00 & 0.60 & $\mathrm{AB}$ & 0.20 \\
\hline First Brood & 5 & 9.45 & $\mathrm{~B}$ & 2.30 & 0.80 & $\mathrm{BC}$ & 0.20 \\
\hline After the Competition Point & 10 & 9.30 & $\mathrm{~B}$ & 2.30 & 0.90 & $\mathrm{C}$ & 0.20 \\
\hline
\end{tabular}

${ }^{*}$ Length and diameter in millimeter $(\mathrm{mm}) ;{ }^{* *}$ Standard deviation; ${ }^{* * *}$ Variance analysis by Scheffé F-test with $5 \%$ significance, + number of individuals analyzed.

The loops of the plasmic membrane are not well structured. An extensive network of tracheoles is observed in NE queens (Figs 1-NE, 2A, B).

The cytoplasm of the secretory cells in $6 \mathrm{D}$ queens, ready to mate, have abundant randomly distributed mitochondria and some Golgi complexes. Basal invagination s of the plasmic membrane are observed, but often not deep into the cell. A non electron-dense basal lamina is also present. Apical invaginations are few, but deeper than in NE queens. There is also amorphous material in the subcuticular space. Granules containing a homogeneous ground matrix with dots of electron-dense material, are also frequently found in the cytoplasm (Figs 1-6D, 2C).

$\mathrm{EH}$ queens show a cytoplasm full of myelinic figures and glycogen deposits. Lysosomes were also present (Figs 1-EH, 2D, E, F).

The most complex ultrastructural organisation of the glandular cells was observed in queens of colonies in the first brood phase (1B). The loop-like infoldings of the plasmic membrane are present and very well organized, being lined with SER. Very electron-dense basal lamina and amorphous material penetrate into the dilated intercellular space. This material probably accumulates in the haemolymph (the amorphous matrix outside the gland, containing electron-dense dots) that is held between the gland and its surrounding muscular sheet (Figs 1-1B, 3A, B, C, D).

The main aspect of the glandular cells of AFC queens is the presence of high electron-dense granules in the cytoplasm. They are round to 

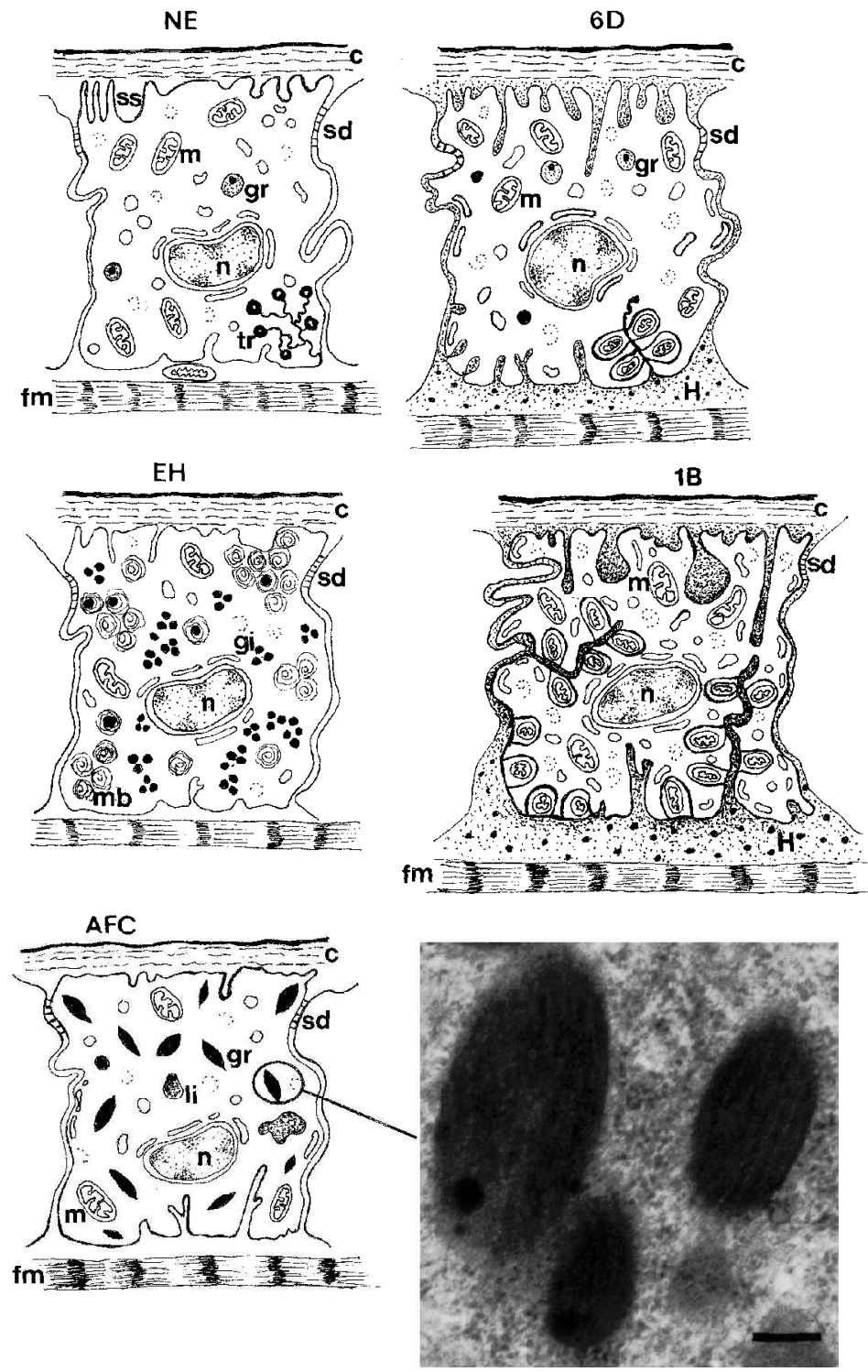

Fig. 1. Schematic representation of the main cell ultrastructural changes of the Dufour's gland of $B$. terrestris during the queen's life cycle. Legenda: NE = newly-emerged queen, $6 \mathrm{D}=$ six day old queen, ready to mate, $\mathrm{EH}=$ end hibernation queen, $1 \mathrm{D}=$ first brood queen, $\mathrm{AFC}=$ after the competition point queen, with detail of cytoplasmic electrondense granules, scale bar $0.1 \mu \mathrm{m} . \mathrm{c}=$ cuticle, gi $=$ glycogen deposits, $\mathrm{gr}=$ intracellular granules, $\mathrm{H}=$ amorphous material accumulated outside gland, $\mathrm{m}=$ mitochondria, $\mathrm{mb}=$ myelinic body, $\mathrm{fm}=$ muscle fiber, $\mathrm{n}=$ nucleus, $\mathrm{sd}=$ septated desmosome, ss = subcuticular space. 

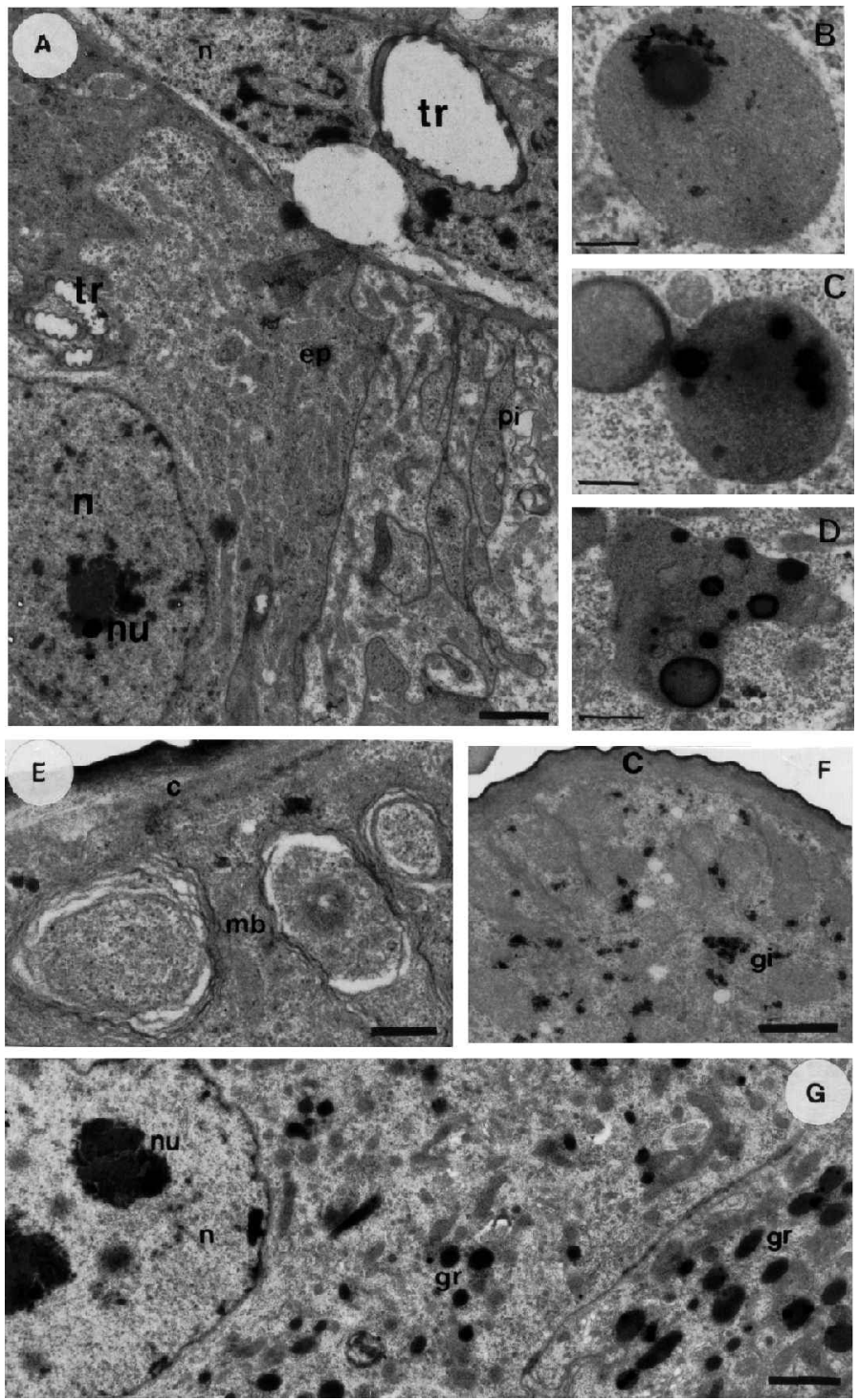

Fig. 2. Main Dufour's gland ultrastructural aspects of the different life phases of the queen. A. Detail of the glandular epithelium (ep) of the NE queen, scale bar $0.2 \mu \mathrm{m}$. B. Detail of a cytoplasmic structure with a discrete double membrane and internal lamellae, scale bar $0.3 \mu \mathrm{m}$. C. Detail of a cytoplasmic ground granule with electron-dense dots inside, scale bar $0.3 \mu \mathrm{m}$. D. Detail of a lisosome, scale bar $0.2 \mu \mathrm{m}$. E. Myelinic bodies $(\mathrm{mb})$ in the EH queen cell luminal region, scale bar $0.2 \mu \mathrm{m}$. F. Glycogen granules (gi) in EH queen cell, scale bar $0.6 \mu \mathrm{m}$. G. Portion of cytoplasm of AFC queen, showing abundant electron-dense granules (gr), scale bar $0.6 \mu \mathrm{m} . \mathrm{c}=$ cuticle, $\mathrm{n}=$ nucleus, $\mathrm{nu}=$ nucleoli, $\operatorname{tr}=$ tracheole. 

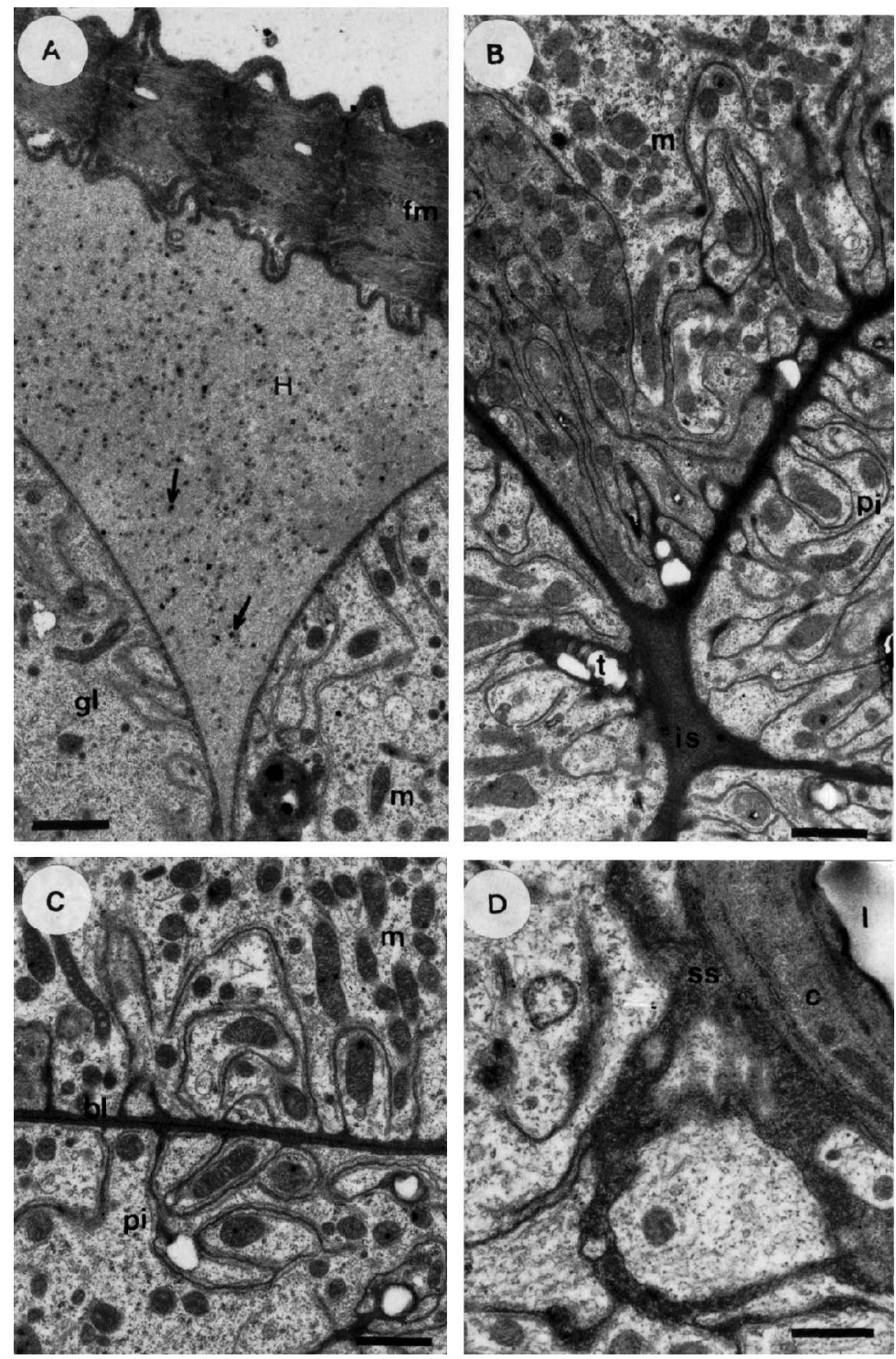

Fig. 3. Dufour's gland cells of the 6D queens. A. Amorphous material from the haemolymph $(\mathrm{H})$ containing little dots (arrows) accumulated between the gland (gl) and sheet of muscle fibers $(\mathrm{mf})$, scale bar $0.6 \mu \mathrm{m}$. B. Very electrondense material in the intercellular space (is), scale bar $0.8 \mu \mathrm{m}$. C. Invaginations of the plasmic membrane (pi) form loop-like infoldings with a single mitochondrion (m) inside, scale bar $0.8 \mu \mathrm{m}$. D. Material accumulated in the subcuticular space (ss) comes from the intercellular space and, probably from that outside the gland (A, B), does not pass into the gland, scale bar $0.3 \mu \mathrm{m} . \mathrm{bl}=$ basal lamina, $\mathrm{c}=$ cuticle, $1=$ lumen, $\mathrm{m}=$ mitochondria. 
elliptical in shape and present a very electron-dense matrix with parallel lamellar organization, resembling cristae, suggesting that these granules may be modified mitochondria (Fig. 1-ACP, detail). Apical and basal invaginations are present, but the former appear to be undergoing a disorganisation process, having an irregular shape and a dilated lumen. The loops are poorly organised, but the intercellular space is very electrondense and sinuous. (Figs 1-ACP, 2G).

\section{DISCUSSION}

The colony development of $B$. terrestris can be characterized by three successive phases: first, the colony is initiated by a solitary queen who produces her first workers by laying diploid eggs; second, once the workers of the first brood emerge, the social phase begins, during which the queen switches from laying diploid eggs to laying haploid eggs, from which males will arise; and third, workers start to lay eggs. In this last phase, mutual overt aggression starts between workers and between egglaying workers and the queen. The transition from the second to the third phase is rapid, and has been termed the competition point (DUCHATEAU \& Velthuis, 1988).

During the life cycle of the queen, it is possible to identify four important physiological phases: 1 . from emergence until the queen becomes ready to mate (6 days old); 2 . the hibernation period; 3 . from the start of egg-laying (first brood) until the competition point; and 4. After the competition point. The development of the queen's Dufour's gland was studied under these different physiological condition s to elucidate its possible function.

The Dufour's gland of B. terrestris increases in size during the queen's life cycle and thus with age. Both length and diameter of the gland are maintained untill the end of the hibernation phase. When the queen lays the first eggs, the size of the gland has increased significantly (Table 1). The gland also undergoes a major increase of its membrane surface during the queen's egg-laying period (1B queens), produced by several plasmic membrane infoldings, and basal or apical invaginations, resulting in an increase in exchange-surface with both the haemolymph and the gland lumen (Figs 3A, B, C, D).

The subcuticular space and the space between the muscle sheet and the gland becomes filled with amorphous material in 6D and 1B queens. This fact may be responsible for the evident increase in the diameter of the gland in both phases (Table 1, Figs 1-6D, 1B). Also the major increase in total glandular area (length times diameter) is reached in $1 \mathrm{~B}$ queens, 
indicating that the gland may be involved in reproduction, perhaps in the egg-marking activity as in Apis (KATZAV-GOZANSKY et al., 1997).

The Dufour's gland appears to undergo restructuration twice: first when the queen is in the hibernation period and second after the competition point. In both phases the apical and basal invaginations and the loops of the lateral and basal plasmic membranes of the glandular cells are low or do not exist. The occurrence of reabsorption in the cell apices is evident from membranous debris, forming myelin figures in this region (Fig. 2E). These results support the probable participation of the Dufour's gland of $B$. terrestris in reproduction.

In B. terrestris the Dufour's gland cells are morphologically similar to those of class I of NOIROT \& QUENNEDEY $(1974,1991)$, but they seem not to have a prominent secretory function, because the cells are very poor in secretion vesicles or granules. Furthermore, morphological evidence shows that at least part of the products sent to the lumen and constituting the secretion, are taken up directly from the haemolymph. This exogenous material may be taken to the lumen from the space between the gland and the muscle sheet through the intercellular space, and is not passing the epithelial cells. The secretion may also be stored in the subcuticular space (Figs 3A, B, C, D).

Since the gland does not have associated oenocytes (a characteristic of the class II cells of NOIROT \& QUENNEDEY (1974, 1991), and its epithelial cells do not show strong evidences of secretory activity (characteristic of class I cells), the gland is composed of a new type of glandular cells, in which most of the constituents of its secretion may come directly from the haemolymph.

The chemical studies about the secretion of Bombus support this theory: the same hydrocarbons present on the exoskeleton are found in the Dufour's gland secretion (TENGÖ et al., 1991; OLDHAM et al., 1994). According to these authors, the composition of the secretion of the gland varies among the individuals of the same species from different colonies and probably the secretion serves for nestmate recognition. One explanation for the differences in the composition of the Dufour's gland secretion among the colonies is the difference in the quality of the food stored in them (HEFETZ et al., 1993). The products of digestion, absorbed by the midgut and delivered to the haemolymph, may be taken up by the Dufour's gland of Bombus; food differences among the colonies are thus reflected in the composition of the secretion.

In conclusion, the Dufour's gland presents changes in its morphology during the life cycle of the queen, reflecting a possible complex function of the gland in B. terrestris. Its development during the life cycle, reaching a higher developmental level in the critical reproduction period, suggests 
that the gland may play some role in reproduction. Perhaps, and more appropriate to social bees, it may supply the queen's eggs with specific pheromones.

\section{ACKNOWLEDGEMENTS}

We are grateful to Dr. MR Dohmen (Department of Experimental Zoology, Utrecht University, Holland) for making available the laboratory facilities and for his support throughout the study, and to Mr. Gideon Zwaan and Dr. Thijs Zandbergen for their substantial technical support. Linguistic advice was given by Laura Cobb. Financial support from Koppert bv enabled FCA to work at Utrecht University, as did FAPESP (Fundação de Amparo à Pesquisa do Estado de São Paulo, proc. No. 96/12243-8).

\section{REFERENCES}

Billen, J.P.J., 1987. New structural aspects of the Dufour's gland and venom gland in social insects. Naturwissenschaften 74: 340-341.

BordAs, M.L., 1894. Appareil glandulaire des hyménoptères. Tese apresenté á la Faculté des Sciences de Paris pour obtenir le grade de docteur Sciences Naturelles. Libraire de l'Académie de Médecine, Paris. Série A, n. 217, 362 pp.

CANE, J.H., 1981. Dufour's gland secretion in the cell linings of bees (Hymenoptera: Apoidea). J. Chem. Ecol. 7 (2): 403-410.

CRUZ-LANDim, C. da, 1967. Ultra-estrutura das glândulas básicas de Bombus e Apis. Cienc. Cult. 19: 266-267.

Duchateau, M.J. \& H.H.W. Velthuis, 1988. Development and reproductive strategies in Bombus terrestris colonies. Behaviour 107: 186-207.

Dufour, L., 1841. Reserches anatomiques et physiologiques sur les orthoptères, les hyménoptères et les névropteres. Mémoires Présenteés par Divers Savants a l'Académie Royale des Sciences de l'Institut de France, 647 pp.

Hefetz, A., 1990. Individual badges and specific messages in multicomponent pheromones of bees (Hymenoptera: Apidae, Bombini). Entomol. Gener. 15: 103113.

Hefetz, A., J. Tengö, G. LüBke \& W. Francke, 1993. Inter-colonial and intracolonial variation in Dufour's gland secretion in the bumble bee species Bombus hypnorum (Hymenoptera: Apidae). In: K. Wiese et al. (Eds.). Advances in life sciences, Sensory system of Arthopods, Vol. 11, p. 469-480.

Katzav-Gozansky T., V. Soroker, A. Hefetz, M. Cojocaru, D.H. Erdmann $\&$ W. FranCKe, 1997. Plasticity of caste-specific Dufour's gland secretion in the honey bee (Apis mellifera L.). Naturwissenschaften 84: 238-241.

Kronenberg, S. \& A. Hefetz, 1984. Comparative analysis of Dufour's gland secretions of two carpenter bees (Xylocopinae: Anthophoridae) with different nesting habits. Comp. Biochem. Physiol. 79B (3): 421-425.

LELlo, E., 1968. Glândulas anexas ao aparelho de ferrão das abelhas (Hymenoptera: Apoidea). Rio Claro: FFCL. Tese de doutorado em Zoologia, Instituto de Biociências, Unesp, 128 pp. 
Noirot, C. \& A. Quennedey, 1974. Fine structure of insect epidermal glands. Annu.Rev. Entomol. 19: 61-80.

Noirot, C. \& A. Quennedey, 1991. Glands, gland cells, glandular units: some comments on terminology and classification. Ann. Soc. Entomol. Fr. (NS) 27: 123128.

Norden, B., B.S.W. Batra, H.M. Fales, A. Hefetz \& G.J. Shaw, 1980. Anthophora bees: unusual glycerides from maternal Dufour's gland serve as larval food and cell lining. Science 207: 1095-1097.

Oldham, N., J. Billen \& E.D. Morgan, 1994. On the similarity of the Dufour gland secretion and the cuticular hydrocarbons of some bumblebees. Physiol. Entomol. 19: 115-123.

RATNIEKS, F.L.W., 1993. Egg-laying, egg-removal, and ovary development by workers in queenright honey bee colonies. Behav. Ecol. Sociobiol. 32: 191-198.

RATNIEKS, F.L.W., 1995. Evidence for a queen-produced egg-marking pheromone and its use in worker policing in the honey bee. J. Apicult. Res. 34: 31-37.

Shimron, O., A. HEFETZ \& J. TENGÖ, 1985. Structural and communicative functions of Dufour's gland secretion in Eucera palestinae (Hymenoptera: Anthophoridae). Insect Biochem. 15: 635-638.

SMith, B.H., R.G. CARLSON \& J. FraZier, 1985. Identification and bioassay of macrocyclic lactone sex pheromone of the halictine bee Lasioglossum zephyrum. J. Chem. Ecol. 11: 1147-1456.

Tengö, J., A. Hefetz, U. Schmitt, G. Lübkes \& W. Francke, 1991. Species specificity and complexity of Dufour's gland secretion of bumble bees. Comp. Biochem. Physiol. 99B: 641-646.

Vinson, S.B., G.W. Frankie, M.S. Blum \& J.W. Wheeler, 1978. Isolation, identification and function of the Dufour's gland secretion of Xylocopa virginica texana (Hymenoptera: Anthophoridae). J. Chem. Ecol. 4: 315-323. 